Vol. 04 No. 01 (2021) : 68-81

Available online at http://jurnal.unissula.ac.id/index.php/fikri/issue/archive

\title{
NILAI-NILAI EDUKATIF DALAM SURAT AL KAUTSAR BESERTA IMPLIKASINYA DALAM KEHIDUPAN (TELA'AH TAFSIR AL QURTHUBI)
}

\author{
Abid Nurhuda ${ }^{1}$ \\ UIN Raden Mas Said Surakarta, Indonesia \\ abidnurhuda123@gmail.com
}

\begin{abstract}
Islam is very concerned about education and its implementation which is based on the Qur'an and alHadith. So one of the words of God that contains educational teachings and contains educational values is the letter Alkautsar verses 1-3 (Tala'ah Tafsir Al Qurthubi). The purpose of this study is to find out the educational values of Islam contained in Surah Al-Kautsar verses 1-3 according to the interpretation of Jami' li Ahkami of the Qur'an by Al-qurthubi and to find out its implications in everyday life. The method used is library or library research with primary data sources namely Jami' Li Ahkami Al-qur'an and secondary data such as books, journals, articles and so on and then collected, processed then analyzed and concluded descriptively. So the conclusion obtained is that in the first paragraph there is an educative value of gratitude, namely acknowledging it with the heart, then saying it verbally and implementing/implementing it with the limbs. While the educational value in the second verse is spiritual value which is manifested in prayer worship (Hablun minallah) and social value which is manifested in qurban worship (Hablun minannas). While the educational value in the third verse is the value of fighting spirit which is reflected in the good deeds of ma'ruf nahi mungkar and the value of toughness that is accompanied by responsibility, all of which are illustrated by that everyone will definitely get a reward according to their deeds.
\end{abstract}

Keywords: Al Kautsar, Al Qurthubi, Educational Value.

\begin{abstract}
Abstrak
Islam sangat memperhatikan pendidikan dan penyelenggaraan-nya yang bersumber pada alQur'an dan al-Hadis. Maka salah satu firman Allah yang berisi tentang ajaran pendidikan dan mengandung nilai-nilai edukatif adalah surat Alkautsar ayat 1-3 (Tela'ah Tafsir Al Qurthubi). Tujuan dari penelitian ini adalah Untuk mengetahui nilai-nilai edukatif Islam yang terdapat dalam surat Al-kautsar ayat 1-3 menurut tafsir Jami' li Ahkami Alqur'an karya Al-qurthubi serta Untuk mengetahui implikasinya dalam kehidupan sehari-hari. Metode yang digunakan ialah kepustakaan atau library research dengan sumber data primer yakni Jami' Li Ahkami Al-qur'an serta data sekunder seperti buku, jurnal, artikel dan selainnya lalu dikumpulkan, diolah kemudian di analisa dan disimpulkan secara deskriptif. Maka kesimpulan yang di peroleh adalah pada ayat pertama terdapat nilai edukatif syukur yakni mengakui dengan hati, lalu di ucapkan dengan lisan dan dilaksanakan/ di implementasikan dengan anggota badan. Sementara nilai edukatif pada ayat kedua ialah nilai spiritual yang mana termanifestasikan dalam ibadah sholat (Hablun minallah) dan nilai sosial yang mana termanifestasikan dalam ibadah qurban (Hablun minannas). Sedangkan nilai edukatif pada ayat ketiga adalah nilai semangat juang yang tergambar dalam amal ma'ruf nahi mungkar dan nilai ketegaran yang di iringi tanggung jawab semua itu tergambarkan dengan bahwa tiap orang pasti akan mendapat balasan sesuai amalannya.
\end{abstract}

Kata Kunci: Al Kautsar, Al Qurthubi ,Nilai Edukatif 


\section{Pendahuluan}

Edukatif dalam KBBI diartikan dengan hal-hal yang berkaitan dengan pendidikan, sedangkan salah satu ahli menyebutkan bahwa Edukatif adalah suatu kondisi yang meberikan pemahaman, pengajaran serta pengetahuan (Abibakr, 2015). Maka edukatif / pendidikan dijabarkan sebagai suatu proses memahami ilmu pengetahuan secara terus menerus bisa berupa budaya maupun cita-cita masyarakat. Dalam bahasa lain, dianggap sebagai proses untuk memberikan sebuah nilai sehingga potensi peserta didik dapat berkembang secara maksimal serta mampu mengatasi tuntutan ataupun tantangan di masa depan. Tujuan dari pendidikan ialah meningkatkan kualitas manusianya agar beriman serta bertakwa kepada Tuhan yang Maha Esa, sebagaimana yang dimaksud dalam Undang-undang Nomor 20 tahun 2003. Lebih dari pada itu bahwa untuk mencerdaskan kehidupan bangsa perlu juga untuk berakhlaq mulia, berilmu, cakap, sehat, kreatif, mandiri, demokratis dan bertanggungjawab. Islampun datang dengan memberikan perhatian yang sangat besar terhadap pendidikan dan penyelenggaraan-nya. Hal ini antara lain, dapat dilihat secara historis umat Islam sudah memiliki peranan yang begitu penting dalam hal pendidikan, yang mana hasilnya kini masih bisa dirasakan. Demikian pula, secara normatif bahwa sumber ajaran Islam yakni al-Qur'an dan al-Hadis diakui oleh umat islam sebagai pedoman terbaik sepanjang masa untuk menjamin keselamatan dunia dan akhirat. Maka firman Allah yang termaktub dalam Alqur'an merupakan suatu rumusan atau kode-kode yang dapat menghantarkan pada nilai, sifat, karakter dan tujuan pendidikan yang hakiki. Dalam memahami firman-firman Alllah tidaklah bisa hanya menggunakan hasil terjemahan atau hanya berdasar pada teks dhahirnya saja karena dapat menyebabkan kerancuan, namun mesti dipahami menggunakan alat-alat keilmuan yang lengkap, dan salah satunya adalah menggunakan ilmu tafsir. Menafsirkan Alqur'an bisa dilakukan dengan beberapa cara, diantaranya Pertama, menafsirkan ayat dengan ayat yang lain. Kedua, menafsirkan ayat dengan hadits Nabi. Ketiga, menafsirkan ayat dengan perkataan sahabat. Keempat, menafsirkan ayat dengan perkataan tabi'in. Meski begitu masih banyak juga yang masih belum mengerti terkait bagaimana memahami firman-firman Allah yang terdapat dalam Alqur'an tersebut, sehingga terkadang tujuan hakiki dari pendidikan yang seharusnya bisa tercapai pun jadi terbengkalai baik itu berupa nilai, sifat ataupun karakternya. Hal itu terbukti dengan mundurnya pendidikan karakter serta merosotnya moral masyarakat (Dewi Purnama Sari, 2017). Oleh karena itu, tidaklah pantas jika hanya terbatas pada pemahaman dan pembelajarannya saja tapi juga harus berimplikasi dan terimplementasikan nilai-nilai pendidikan dari ayat qur'an tersebut dalam kehidupan sehari-sehari. Dalam al-Quran sendiri, terdapat banyak firman Allah yang berisi tentang ajaran pendidikan dan mengandung nilai-nilai edukatif, salah satunya adalah surat Alkautsar ayat 1-3 sehingga dalam kesempatan ini penulis tertarik untuk sedikit mengulas hal tersebut menurut tafsir Imam Al-qurthubi.

Dari latar belakang masalah sebagaimana yang telah diuraikan di atas, paper ini membahas terkait nilai-nilai edukatif Islam yang terdapat dalam surat 
Al-kautsar ayat 1-3 menurut tafsir Jami' li Ahkami Alqur'an karya Al-qurthubi serta implikasi dan implementasi nilai-nilai pendidikan ataupun edukatif dari surat tersebut dalam kehidupan sehari-hari.

\section{Metode}

Metode yang digunakan dalam penelitian ini adalah metode kepustakaan atau library research yakni dengan serangkaian kegiatan yang berkaitan pada pengumpulan data pustaka (Mahmud, 2011). Abdul Rahman menjelaskan lebih rinci lagi bahwa data atau informasi tersebut bisa diperoleh dari berbagai hal diantaranya catatan, majalah, buku, dokumen serta kisah-kisah sejarah. Sumber data yang digunakan penulis disini terdiri dari dua hal yaitu primer dan sekunder, data primer yang di maksud adalah data yang langsung dari tangan pertama serta berhubungan dengan objek penelitian maka yang digunakan di sini adalah kitab Jami' Li Ahkami Al-qur'an karya Imam Al-qurthubi (Saifuddin Azwar, 2009). Sedangkan data sekundernya adalah sejumlah informasi yang menguatkan serta mendukung sumber yang ada dalam data primer seperti buku, jurnal, artikel dan selainnya yang berfungsi untuk memperluas wawasan dan pengetahuan yang berkaitan dengan pemecahan masalah penelitian diatas. Lalu pengumpulan data yang dilakukan adalah dengan literer yakni dengan mengumpulkan bahan-bahan yang berkesinambungan dengan objek pembahasan yang diteliti. Dilanjutkan dengan mengolah data yang kemudian diselaraskan serta dianalisa lalu diambil kesimpulan secara deskriptif dari datadata yang telah terkumpul.

\section{Hasil dan Pembahasan \\ Biografi Imam Al-qurthubi}

Nama lengkap beliau adalah Abu Abdillah Muhammad bin Ahmad bin Abi Bakr bin Farh al-Qurthubi dan merupakan salah satu ulama besar Eropa yang telah berkontribusi besar dalam perkembangan hazanah keilmuan Islam, terkhusus lagi dalam kajian tafsir al-Qur'an. Beliau terkenal dengan ulama yang zuhud yakni rela meninggalkan kesenangan dunia demi mengedepankan kepentingan akhiratnya. Beberapa karya yang telah ditorehkan beliau antara lain, Al-Asna fi Sharh Asma Allah al-Husna wa Sifatih, Al-Tidzkar fi Afdal alAdzhkar, Al-Tadhkirah fi Ahwal al-Mawta wa Umur al-Akhirah,dan masih banyak lagi. Sedangkan karya yang paling fenomenal dari karangannya adalah kitab tafsir Al-Jami' li Ahkam al-Qur' an wa al Mubayyin lima Tadlammanah min al-Sunnah wa Ay al-Furqan yang berisi berisi himpunan hukum al-Qur'an serta mencakup aspek qiro' at, fiqih, I'rob, nahwu, balaghoh, dan penjelasan terhadap isi kandungannya dari Sunnah dan ayat al-Qur'an.

Secara umum, kitab yang beliau susun menampilkan satu ataupun lebih ayat dalam sebuah pembahasan sesuai dengan urutan surat dalam mushaf Alqur'an. Beliau merinci masalah-masalah yang terkait dengan pembahasan tersebut kemudian dilakukan langkah-langkah penafsiran sebagai berikut : 1) Menyebutkan keutamaan atau keistimewaan surat al-Qur'an yang akan dibahasnya; 2) Membahas nama-nama surat tersebut, lalu terkait dengan sebab turunnya, serta kajian hukum yang ada pada ayat tersebut;3) Menyebutkan ayat- 
ayat lain yang berkaitan serta hadis-hadis nabi sebagai bukti dan dalil; 4) Mengupas ayat dari segi bahasa, dengan menggunakan sya'ir-sya'ir arab sebagai rujukan kajian; 5) Mengutip dan mengambil pendapat ulama langsung dari sumbernya sebagai alat untuk menjelaskan keterangan hukum yang berkaitan dengan pokok pembahasan ayat. 6) Mendiskusikan pendapat ulama disertai dengan argumentasi masing-masing, dilanjutkan dengan melakukan tarjih yakni mengambil pendapat yang dianggap paling kuat dan benar.

Dari sistematika gambaran umum penafsiran Al-qurthubi di atas dapat diperoleh bahwa kalau dilihat dari sumbernya maka masuk kategori tafsir bi aliqtirani karena menggabungkan antara penafsiran bi al-ma'tsur dan bi al-ra'yi. sedangkan jika ditinjau dari cara penjelasannya maka masuk metode muqarin karena manafsirkan ayat Alqur'an dengan (ayat lain, hadist nabi, perkataan sahabat, tabi'in dan tokoh-tokoh tafsir, lalu dikompromikan), Adapun jika dilihat dari keluasan penjelasannya maka masuk tafsir tafsili karena banyak mengutip pendapat ulama dari aspek bahasa, fiqih, dan selainnya, lalu jika dilihat dari sistematika penulisannya merupakan tafsir tahlili atau mushafi karena memulai kitab tafsirnya dari surat al-Fatihah dan diakhiri dengan surat an-Nas dan terakhir untuk corak penafsirannya maka bercorak fiqhi karena dalam tafsirnya lebih banyak mendiskusikan persoalan-persoalan fiqih kertimbang persoalan yang lain. Tafsir Al-qurthubi memiliki beberapa kelebihan yakni tidak fanatik madzhab, menukil langsung kepada sumbernya, mendiskusikan perbedaan pendapat, cerdas dalam menyampaikan kritik, memperhatikan berbagai hal yang berkaitan dengan ayat al-qur'an seperti bahasa, hukum, asbab nuzul, dan selainnya. Meski begitu tafsir ini juga memiliki beberapa kekurangan antara lain, masuknya kisah isroiliyyat, adanya pokok bahasan yang keluar dari tema ayat, dan terkadang salah dalam menukil orang/ riwayat. Terlepas dari kelebihan dan kekurangannya, Tafsir ini sudah menjadi rujukan bagi para pecinta kajian Al-qur'an sebab pengarangnya merpakan ulama besar yang berwawasan luas serta bersifat toleran dan tidak terlalu fanatik terhadap madzhab. Beliau menghabiskan dan mengorbankan waktuwaktunya untuk mengabdi kepada agama hingga akhirnya berpulang menghadap Allah pada malam senin tanggal 9 Syawal $671 \mathrm{H}$ di Kairo Mesir. Beliau telah mencatatkan sejarah hidupnya dengan tinta emas yang selalu menjadi kebanggan umat Islam dari generasi satu ke generasi lainnya (Moh. Jufriyadi Sholeh, 2018).

\section{Surat Al Kautsar}

Surat Al Kautsar atau ada yang menamakan dengan "Surat An Nahr" karena ada kata wanhar pada ayat ke 2, adalah termasuk salah satu surat yang paling pendek dalam Alqur'an sebab hanya terdiri dari 3 ayat dan berbunyi :

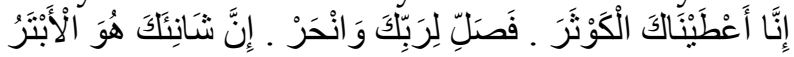

Artinya : "Sesungguhnya kami telah memberi-Mu (wahai Muhammad) dengan nikmat yang banyak. Maka solatlah karena Tuhanmu (Allah) dan berkurbanlah. Sesungguhnya orang yang membencimu adalah orang yang terputus (dari rahmat Allah)."

3 ayat yang dikemukakan diatas merupakan bunyi lengkap dari surat $\mathrm{Al}$ Kautsar yang mana ulama berbeda pendapat mengenai masalah dimanakah 
surat tersebut di turunkan. Ada yang berpendapat diantaranya Ibnu Abbas, Alkalbi dan Muqotil bahwa surat tersebut diturunkan di Makkah sehingga di anggap sebagai surat makiyah. Sementara ulama lain seperti Hasan, Ikrimah, Qotadah dan Mujahid berpendapat bahwa surat tersebut di turunkan di Madinah sehingga di anggap kategori surat madaniyah. Penyebab perbedaan pendapat tersebut di latar belakangi dengan adanya 2 riwayat dari sahabat yang berlainan terkait dengan penjelasan Asbabun Nuzul dari surat Al Kautsar, yang mana sahabat pertama yakni Ibnu Abbas meriwayatkan bahwa saat itu nabi sedang duduk-duduk bersama para sahabatnya lalu tiba-tiba datanglah salah seorang pembesar quroisy yakni A's bin Wail (dalam riwayat lain adalah Ka'ab bin Al Asyrof) yang menghampiri beliau lalu mengejek dengan sebutan "Dzaka Abtar" yang berarti Rugi engkau wahai Muhammad dan dalam pandangan orang-orang arab kala itu adalah merupakan sebuah aib apabila seorang pemuka atau pembesar dari sebuah suku namun tidak memiliki anak laki-laki yang kelak akan melanjutkan serta melanjutkan dakwah risalahnya. Bagaimana tidak? Barubaru saja Rosululloh kehilangan anak tercintanya yakni Abdulloh bin Muhammad sehingga orang-orang quroisy mengira ajaran rosul akan terhenti setelah beliau meninggal/wafat karena tidak adanya keturunan anak laki-laki pada diri beliau yang akan bisa melanjutkan dakwahnya, namun allah membantah sangkaan dan anggapan mereka sehingga diturunkanlah surat Al Kautsar.

Dari asbabun nuzul yang pertama ini sebagian ulama menyimpulkan bahwa surat tersebut masuk kategori makiyyah karena berkaitan dengan orangorang quroisy Makkah. Sementara sahabat kedua Anas bin Malik meriwayatkan bahwa sebab turunnya surat tersebut adalah ketika sedang berkumpul dengan para sahabatnya tiba-tiba Rosululloh menundukkan kepala sejenak lalu sesaat kemudian beliau mengangkat kembali kepalanya dan langsung tersenyum dihadapan para sahabat, hal itu membuat mereka penasaran sehingga salah seorang sahabat nabi pun bertanya kepada beliau : Wahai Rosululloh apa yang membuat engkau tiba-tiba tersenyum Bahagia? Maka rosul menjawab : tadi telah turun kepada ku sebuah surat. Maka rosulpun membacakan surat Al Kautsar tersebut kepada para sahabatnya. Dari asbabun nuzul yang kedua inilah sebagian ulama menyimpulkan bahwa surat tersebut masuk kategori Madaniyyah karena sahabat Anas bin Malik masuk Islam ketika Rosululloh sudah melakukan hijrahnya ke Madinah (Riham Abu Iyyas: 2021).

\section{Ayat Pertama}

Ayat yang pertama dari surat Al Kautsar adalah dalam tafsir Syarkh AlBarshawi Ala Tafsir Albadhowi disebutkan bahwa kata memiliki makna penekanan dan sumpah sebagaimana kebiasaan orang-orang arab terdahulu saat meyakinkan sebuah ucapan yakni dengan Waw atau Lam, Seperti kata Wallahi ataupun Lillahi. Sedangkan أَعْطَيْنَاكَ maka bentuk dari fi'il madhi yang berarti bahwa pemberian kelak di akhirat lebih banyak dari pada pemberian saat ini yang ada di dunia yang mana jika di lihat dari aspek kenabian maka Rosul telah Allah limpahkan kedermawanan dan kemuliaan (Abdulloh Ahmad Ar-rowi, 2019). 


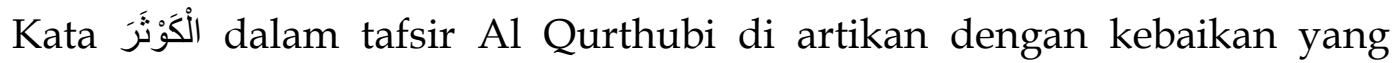
banyak. Dalam perpektif beliau ada beberapa makna terkait hal tersebut, diantaranya : 1) Kebaikan yang banyak diartikan dengan begitu besarnya jumlah sahabat dan pengikut nabi; 2) Bisa diartikan juga dengan sungai disurga ataupun telaga nabi disana; 3) Ada juga yang mengartikan bahwa nikmat yang banyak tersebut berupa kenabian dan Al Qur'an; 4) Ada juga yang mengartikan dengan islam dan di ringankannya syariat; 5) Bisa juga diartikan dengan diangkatnya nama Rosululloh baik di langit maupun di bumi; 6) Selain itu ada juga yang memaknai yang di maksud dengan nikmat yang banyak tersebut adalah cahaya di hati nabi, terijabahnya doa dan syafa'at.

Beberapa pendapat serta perpektif dari berbagai ulama yang telah disebutkan oleh Imam Alqurthubi diatas, maka beliau berhujjah bahwa yang paling kuat dari sekian banyak pendapat yang ada adalah pendapat yang mengatakan bahwa makna dari الُْْْرَ adalah kebaikan yang banyak yakni sungai ataupun telaga nabi di surga sebagaimana dalam hadist shohih yang diriwayatkan oleh Imam muslim dan juga Imam ahmad (Abu Abdillah AlQurthubi, 2006). Hal ini juga senada dengan pendapat Ar Rowi yang mengatakan bahwa Qodhi bin Iyyad pernah mengucapkan jika semua hadist yang menyebutkan bahwa أَكْوَثَ merupakan telaga nabi hampir seluruhnya shohih sehingga mengimaninya dihukumi wajib, sementara mempercayainya adalah bagian dari keimanan (Abdulloh Ahmad Ar-rowi, 2019).

\section{Ayat Kedua}

Adapun ayat kedua dari surat Al Kautsar ialah فَصَلِ لِرَبَتِكَ وَانْحَر maka dalam tafsir Al Qurthubi kata فَ فَلْ bermakna "maka solatlah" memiliki beberapa penjelasan, diantaranya : 1) Ada yang berpendapat yang di maksud dengan solat adalah solat 5 waktu karena ia merupakan rukun dalam islam dan merupakan pondasi dasar dalam agama; 2) Ada juga yang berpendapat bahwa yang di maksud solat disini ialah solat subuh karena kalimat solat dalam ayat 2 tersebut bebarengan dengan kalimat "An-Nahr" dan ia terletak sebelum kejadian Nahr/ berkurban maka sudah tentu tidak ada lagi solat yang wajib di lakukan sebelum peristiwa itu selain solat subuh di muzdalifah; 3) Namun ada pula yang berpendapat bahwa yang di maksud solat di sini yakni solat Idul Adha sebab penyebutan dua kata secara bersama-sama itu mendakan waktu yang dekat, sebagaimana tangan kanan dan kiri yang mana keduanya saling melengkapi dan saling mengisi sehingga tidak ada ibadah yang lebih dekat kepada peristiwa kurban tersebut selain solat hari raya.

Sementara kalimat لِرَبَّ maka menurut Ar Rowi dimaknai dengan pengagungan dan penekanan atas pelaksanaannya yang wajib sehingga harus ikhlas serta hanya boleh mengharap keridhoan Allah semata. Imam Az Zarkasyi mengatakan bahwa ayat ke 2 ini merupakan antonim atau lawan dari surat sebelumnya yakni surat Al Mau'n yang mana dalam surat tersebut Allah telah mensifati orang-orang munafik dengan berbagai sifat buruk. Salah satunya adalah suka meninggalkan solat (lalai dalam waktu serta pelaksanaannya) dan وَانحَر malah berbuat riya' (Adil Muhammad Kholil, 2017). Sedangkan kata menurut Al Qurthubi adalah berkurban setelah melaksanakan solat idul adha 
maka barang siapa yang menyembelih hewan qurban sebelum solat hari raya di dirikan, maka hal itu di anggap sebagai sedekah untuk keluarganya saja dan bukan dianggap berkurban untuk sesama. Dalam berkurban di bolehkan memilih antara onta, sapi ataupun kambing sesuai dengan kemampuan dan kondisi setempat (Abu Abdillah Al-Qurthubi, 2006). Dalam hal ini juga merupakan kebalikan dari surat sebelumnya yakni Al Mau'n ayat 7/ terakhir yang memiliki arti "dan mereka (orang munafik) tidak mau/ enggan dalam membayar zakat, dalam Riwayat yang lain di jelaskan enggan menolong orang lain dengan memberikan barang yang baik. Maka semakin jelas bahwa berkurban/ mengorban sesuatu demi orang lain merupakan antitesa dari enggan membayarkan zakat, ibarat dua sifat yang jauh berbeda yakni dermawan dan kikir. Selain itu dalam ayat kedua ini juga menunjukkan bahwa puncak dari ibadah jiwa dan raga adalah sholat, sementara puncak dari ibadah harta adalah berkurban (Abdulloh Ahmad Ar-rowi, 2019) .

\section{Ayat Ketiga}

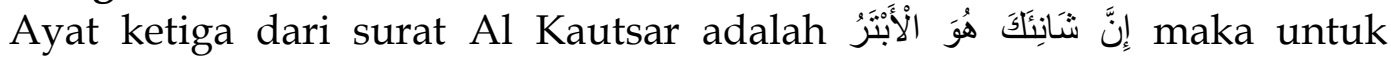
penjelasan dari kata إنَّ شَانِنَكَ ini adalah "sesungguhnya orang yang membencimu” yakni seseorang yang bangga, bahagia dan bersenang-senang di atas penderitaanmu. Sebab kebencian itu merupakan induk dari permusuhan. Meski begitu hukum yang berlaku disini adalah khusus bagi orang-orang yang terus menerus membenci dan belum mendapat hidayah, adapun orang yang mendapat hidayah maka induk tersebutpun bisa berubah dari yang tadinya itu permusuhan malah menjadi persahabatan, sebagaimana kisah Umar bin Khattab dan Kholid bin Walid yang mana dulu merupakan musuh besar islam namun ketika Allah telah memberikan hidayah, maka orang-orang tersebut berubah

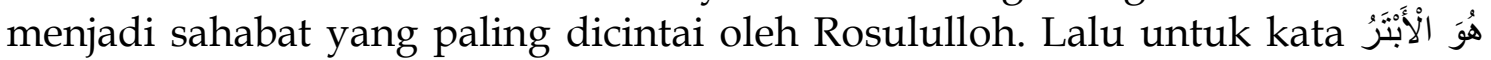
menurut Al Qurthubi adalah kebiasaan orang-orang arab dahulu, yang mana jika ada orang yang memiliki anak laki-laki dan perempuan lalu yang meninggal anak laki-lakinya sementara yang tersisa adalah anak perempuannya saja sering disebut dengan الََْبْنَر namun disini dimaknai dengan "terputusnya seseorang dari kebaikan dunia dan akhirat". Dalam riwayat lain ada yang menyebutkan saat itu Rosululloh menyeru dan mengajak orang-orang quroisy agar masuk islam, namun mereka malah menghardik serta mencela Rosul dengan sebutan Abtar, yakni orang yang terputus keturunan anak laki-lakinya sebab kala itu baru saja meninggal putra beliau ada yang bilang nama putra beliau adalah Ibrahim, ada lagi yang lain yakni Qosim dan ada yang bilang Abdulloh. Sehingga Allah langsung menolong Rosulnya lalu membalas perkataan mereka dengan turunnya ayat ketiga dari surat Al Kautsar yang mana hakekat dari terputus adalah diri mereka sendiri karena tidak mau memeluk agama islam. Selain itu ada juga yang berpendapat bahwa Abtar ialah orang laki-laki yang sendirian tidak punya putra maupun saudara laki-laki. Namun ada juga yang berpendapat jika Abtar adalah orang yang selalu terkena dampak buruk sebab tidak ada kebaikan pada dirinya (Abu Abdillah Al-Qurthubi, 2006).

Nilai-Nilai Edukatif dalam Surat Al Kautsar 
Berdasarkan penjelasan dari 3 ayat surat Al Kautsar diatas, maka bisa diambil beberapa nilai edukatif atau pendidikan pada tiap ayatnya sebagai modal serta pondasi bagi kita untuk terus mempelajari dan mendalami ayat-ayat Al-Qur'an, yakni :

1. Dalam ayat pertama dijelaskan bahwa Allah telah memberikan Al Kautsar kepada Rosululloh, dan para ulama berbeda pendapat terkait makna tersebut. Ada yang menyebut itu merupakan telaga, sungai, kebaikan yang banyak, syafaat dan lain sebagainya sebagaimana yang terdapat dalam Tafsir Al Qurthubi. Namun terlepas dari perbedaan tersebut, hakekatnya ialah Allah ingin mengarahkan serta mengingatkan Rasulullah agar selalu bersyukur atas segala nikmat dan karunianya. Maka dalam arti yang luas hal tersebut juga menyentuh kepada umat dan pengikut Rosululloh yang senantiasa mengikuti jejak beliau. Selain itu, hal ini juga menunjukkan cara Allah untuk mendidik hamba-hamba Nya supaya bisa meniru, mengikuti Rosul dan menjadikan beliau sebagai panutan dalam kehidupan (Hamzah Djunaid, 2014). Karena rosululloh merupakan suri tauladan terbaik dalam menjalankan rasa syukur kepada Allah, bagaimana tidak? Beliau sudah di jamin oleh Allah masuk surga dan diampuni semua kesalahan serta dosanya sebagaimana dalam sebuah hadist yang berbunyi :

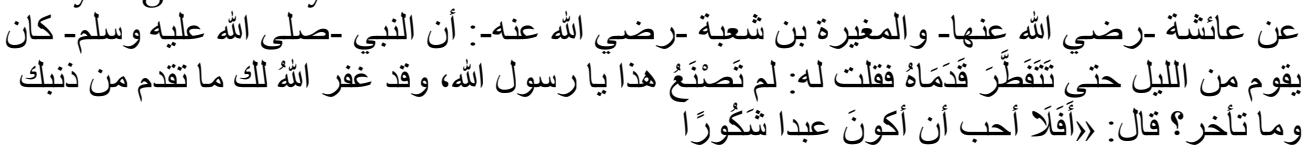

Artinya : "Dari Aisyah dan Mughiroh berkata bahwa Nabi Shollahu A'laihi Wasalam dahulu suka melakukan sholat tahajud/ sholat malam sampai pecah-pecah bahkan bengkak pada dua tumit di kakinya, maka akupun bertanya kepada Rosul : Wahai Rosululloh, kenapa engkau melakukan hal ini, bukankah Allah telah mengampuni semua dosa mu yang lalu dan juga dosa yang akan datang? Maka beliaupun menjawab : Tidak bolehkah Aku menjadi seorang hamba yang bersyukur?." (Muttafaqun A'laih)

Maka dapat di pahami bahwa nilai edukatif yang bisa diambil dari ayat pertama surat Al Kautsar adalah nilai syukur. Begitu banyak nikmat yang Allah limpahkan kepada umat nabi Muhammad diantaranya nikmat iman, nikmat islam, nikmat sehat, nikmat sempat, nikmat umur, nikmat harta benda dan selainnya. Bahkan disebutkan dalam ayat Al Qur'an saking banyaknya Allah memberikan limpahan karunia. nikmat serta pemberian yang tak terhingga sampai-sampai manusia tidak akan mampu menghitungnya. Allah Subhanahu Wata'ala berfirman :

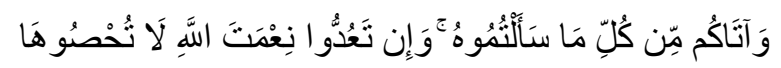

Artinya : "Dan Dia (Allah) telah memberikan semua yang kamu minta, dan jika kamu hendak mencoba untuk menghitung nikmat/ pemberian/ karunia dari Allah tersebut niscaya kamu(sekali-kali) tidak akan mampu untuk menghitungnya" (QS : Ibrahim ayat 34) 
Karena sebab hal diatas, menuntut kita yakni manusia terkhusus lagi umat Muhammad adalah untuk selalu juga berbuat syukur kepada Allah dan itu haruslah terimplikasi dalam kehidupan dengan cara ; mengakui dengan hati, lalu di ucapkan dengan lisan dan dilaksanakan/ di implementasikan dengan anggota badan sehingga harapannya nanti nikmat yang datang jadi lebih baik, lebih banyak, lebih berkah dan lebih bermanfaat sebab rasa syukur di ibaratkan seperti magnet yang mampu menarik banyak kebaikan agar menghampiri diri kita (Mila Fatmawati dkk, 2018).

2. Pada ayat kedua dari surat Al Kautsar di jelaskan dalam tafsir Al Qurthubi ialah hendaklah engkau solat. Maka makna perintah sholat disini para ulama berbedapa pendapat, ada yang mengatakan jika yang dimaksud adalah sholat wajib sementara ulama lain ada yang berpendapat bahwa yang di maksud disini adalah sholat sunah. Terlepas dari perbedaan tersebut, maka jika diambil makna sholat secara umum adalah bentuk dari komunikasi seorang hamba kepada Sang Pencipta sehingga diperlukan hati yang khusyu' yakni seluruh indera harus sepenuhnya berkonsentrasi pada shalat, sementara lubuk hatinya meyakini bahwa tidak ada sesuatupun di alam semesta ini yang patut untuk disembah selain Allah. Lalu dilanjutkan dengan ketenangan anggota tubuh dalam setiap pergerakan yang mana merupakan aktifitas jasad dan lahir dari sholat (Adriantoni, 2019). Aktifitas dalam sholat dari takbir hingga salam dianggap sebagai dzikrullah yang mana harus dimengerti, direnungi, dipahami, dan dihayati agar mencapai peranan tertinggi dan teristimewa sebab meskipun seseorang sudah baik amalannya namun dia tidak melaksanakan sholat atau bahkan lalai niscaya amalan lain tersebut menjadi sia-sia. Hal itu juga disebutkan dalam surat Al Ma'un ayat empat yang mana orang lalai, berbuat riya' dan meninggalkan sholat digelari dengan Wail yang berarti sungguh celaka.

Maka dapat diambil nilai edukatif yang terdapat pada ayat 2 dari surat Al Kautsar terkait masalah sholat adalah nilai spiritual. Sebab dalam sholat lebih dominan mengatur hubungan hamba dengan Allah atau biasa dikenal dengan Hablun Mina Allah, perintah sholat tersebut juga merupakan bentuk pendidikan Allah kepada hamba-hambanya terkhusus lagi adalah umat Muhammad yang beriman. Dalam perintah sholat tersebut rosul diajarkan untuk ikhlas dan hanya mengharap Allah semata berbeda serta berbanding terbalik dengan orang munafik yang melakukan sholat diiringi dengan rasa riya'. Pernyataan firman Allah tersebut mengandung makna umum dengan maksud umum dan khusus yang berarti ditujukan secara umum kepada umat nabi dan secara khusus kepada Rosululloh (Kasimah Kamaruddin dkk, 2021). Maka dalam pelaksanaan nilai spiritual yang di maksud di sini adalah sholat, ataupun melaksanakan ibadah lainnya maka haruslah ikhlas yang mana merupakan salah satu syarat diterimanya sebuah amal perbuatan, sedangkan syarat lain ialah sesuai dengan petunjuk Rosululloh. Betapa tidak? Amalan yang keliatan kecil namun apabila diiringi dengan 
keikhlasan kepada Allah niscaya akan diterima dan dilipat gandakan pahalanya. Begitu pula sebaliknya, Amalan yang besar bisa berubah menjadi kecil di mata Allah hanya karena tidak murninya sebuah niat (Sulman dan Nur Alim Hamzah, 2019). Jadi dapat disimpulkan dalam pelaksanaan nilai spiritual harus dibarengi dengan rasa ikhlas kepada Allah agar ibadah yang dilakukakan bisa bernilai serta berkualitas disisi Allah Subhanahu Wata'ala, terutama masalah sholat.

Nilai edukatif selanjutnya yang masih ada pada lanjutan ayat kedua dari surat Al Kautsar adalah nilai sosial yang mana tercermin dalam kalimat "wanhar" yang berarti berkurbanlah. Berkurban merupakan bentuk ketundukan dan kepatuhan kepada Allah Azza Wajalla, selain itu juga memiliki makna rela memberikan apapun atau berapapun yang dimiliki bahkan hal yang sangat dicintaipun dikorbankan demi mendapatkan keridhoan Allah Swt (Firdaus Aulia, 2020).Maka berkurban adalah bentuk representasi jalan untuk mendekatkan diri kepada-Nya sebagai rasa syukur atas nikmat yang diberikan, sebab hakekat dari kekayaan ialah sekedar titipan Allah. Dalam berkurban memberikan manfaat bagi pelakunya yaitu dengan hilangnya sifat serta karakter buruk yang ada dalam diri manusia, seperti sifat tamak, serakah, rakus, dan ingin menang sendiri, sehingga ketika hilang semua sifat buruk tersebut muncul kepedulian sosial kepada sesama yakni dengan cara mengeluarkan infaq, mengajarkan ilmu kepada yang lain, wakaf, qurban, shadaqah, dan juga zakat (Dahliati Simanjuntak, 2019).

Jadi dalam ayat kedua ini lengkap dan berimbang kandungan nilai edukasinya yang mana terdiri dari nilai spiritual dan nilai sosial yakni memperhatikan hubungan antara hamba dengan Allah (Vertikal) dan hubungan hamba terhadap sesamanya (Horizontal).

3. Pada ayat ketiga dari surat Al Kautsar dijelaskan dalam tafsir Al Qurthubi ialah orang yang membenci dakwah rosul dan juga ajarannya akan celaka dan terhalang dari rahmat Allah. Hal itu menunjukkan betapa agung Rosululloh dan ajaran nya sehingga Allah sendiri yang langsung turun tangan untuk membantu dan melindungi beliau (Adil Muhammad Kholil, 2019). Selain itu, ayat ketiga tersebut juga merupakan penghibur bagi beliau dan sebagai motivasi juga agar jangan sampai berkecil hati dengan ujaran kebencian musuh-musuh islam, baik saat dicela, diejek ataupun dihardik apalagi sampai berputus asa sehingga diperlukan respon yang ideal agar terbangun keharmonisan hubungan sosial di tengah masyarakat dan Allah sendiri yang mencontohkan hal tersebut dalam ayat tadi (Miftahur Ridho, 2018). Bukan itu saja Rosul bahkan mendapatkan tantangan mulai dari isu yang tidak benar, pemboikotan sampai hampir dibunuh oleh orang-orang quoisy. Namun Rosululloh tidak pernah sedikitpun mundur meski di iming-imingi akan di berikan harta, tahta dan juga wanita, Rosululloh malah menjawab orang-orang yang menghalangi dakwah beliau dengan berkata : seandainya mereka meletakkan matahari di tangan kanan ku dan bulan di tangan kiriku agar 
aku berhenti untuk berdakwah/ berhenti menyeru orang-orang kepada ajaran islam, sungguh sekali-kali aku tidak akan melakukannya. Begitu antusias dan semangat Rosul dalam mengemban amanah serta ajaran islam ini sehingga terimplikasi terkait nilai semangat tadi ke dalam amar ma'ruf nahi munkar yang berarti mengajak manusia kepada kebaikan dan melarang dari kemungkaran.

Disamping nilai semangat juang dakwah, ada juga nilai edukatif lain yakni nilai ketegaran dan juga kelapangan hati Rosul dalam ayat tadi yang mana tidak membalas sumpah serapah buruk mereka, dan bukan cuma pada peristiwa ini saja namun sering kali beliau membalas keburukan-keburukan orang yang di dakwahi dengan akhlak terpuji dan kebaikan. Bahkan tak jarang Rosul malah mendoakan keselamatan agar mereka diberikan hidayah sebagaimana tercermin dari kata-kata beliau yang terbalut dalam doa menghadapi masa-masa sulit dari perlakuan kasar dan keras penduduk Thaif. Karakter, akhlak terpuji dan sifat baik yang terbangun dalam diri seseorang memang sangat penting, namun tidak kalah penting pula dukungan dari lingkungan agar tak mudah menyerah sebagaimana Rosul yang di dukung oleh orang-orang sekitarnya mulai dari Khodijah, Keluarga, Abu bakar, Sahabat-sahabat dan selainnya (M. Fathir Ma'ruf Nurasykim, 2019). Dari nilai ketegaran yang disebut diatas, maka mesti dibarengi dengan nilai tanggung jawab sebagaimana kisah dari asbabun nuzul surat Al Kautsar yaitu orang quroisy yang mencibir Rosul dengan abtar, namun pada akhirnya kalimat tersebut dikembalikan oleh Allah kepada diri mereka sendiri karena setiap orang akan mengemban amanah/pertanggung jawaban sesuai dengan apa yang telah diperbuatnya (Inayatul Hidayah, 2019).

Implikasi nilai tersebut di era saat ini adalah letak titik nilai semangat juang atau jihad dalam berdakwah yang mana kalau dulu bangsa-bangsa islam yang berjuang demi untuk kemerdekaan wilayah dan mempertahankan haknya namun sekarang orang-orang mulai berjuang untuk menguasai teknologi dan informasi agar tidak dikendalikan oleh musuh-musuh islam sehingga terbebas dari sifat-sifat kejahilan modern yakni dengan pendekatan hikmah. Sayid Quthub berpendapat bahwa dakwah dengan pendekatan serta metode hikmah akan terwujud jika memperhatikan beberapa hal diantaranya keadaan /situasi orang-orang yang didakwahi, memperhatikan materi dakwah yang disampaikan dan terakhir adalah memperhatikan cara penyampaian materi dakwah dengan variasi yang sesuai (Abdul Hamid, 2017). Selain itu implikasi dalam kehidupan saat ini jika memahami makna yang tersirat dari ayat ke 3 surat Al Kautsar diatas niscaya para dai, para mubaligh serta terkhusus lagi umat islam akan berdakwah dengan ikhlas dalam melakukan amal ma'ruf dan nahi munkar. Tidak akan mudah Baper (Bawa Perasaan) ataupun putus asa ketika ada orang yang mencemooh atau bahkan membencinya justru dia akan belajar meniru serta meneladani dari ketegaran Rosul dan bisa memahami arti dari nilai tanggung jawab karena segala yang ada di dunia ini akan sirna sedangkan 
yang kekal abadi adalah kehidupan akhirat, maka jadikan keridhoan Allah itu sebagai suatu hal utama yang harus dicari serta semangatlah dalam menggapainya ( Ari Abi Aufa, 2019).

\section{Kesimpulan}

Dari sedikit pemaparan di atas, ada beberapa hal yang dapat dikemukakan sekaligus disimpulkan terkait dengan nilai-nilai edukatif atau pendidikan dalam surat Al Kautsar beserta implikasinya dalam kehidupan menurut pemikiran Imam Al Qurthubi dalam kitab tafsir Jami' Li Ahkami Alqur'an disertai dengan beberapa tambahan dari sumber data sekunder, yakni sebagai berikut :

1. Bahwa surat Al Kautsar memiliki nama lain surat "An Nahr" dan merupakan salah satu surat terpendek dalam Al Qur'an karena hanya terdiri 3 ayat. Para ulama berbeda pendapat mengenai kategorinya, sebagian ulama ada yang menganggap surat tersebut makiyyah sedangkan yang lain menganggapnya sebagai surat madaniyyah. Hal itu disebabkan karena adanya perbedaan pendapat diantara para ulama mengenai Asbabun Nuzul dari surat Al Kautsar.

2. Bahwa ayat pertama terkait dengan kata Al Kautsar memiliki banyak makna diantaranya nikmat yang banyak, tercurahkannya kebaikan, sungai, telaga nabi dan masih banyak lagi. Adapun ayat kedua membahas terkait makna Sholli yakni perintah sholat yang mana disana juga terdapat khilaf, ada yang menyebut sholat wajib sementara yang lain sholat sunnah. Sedangkan ayat ketiga memaparkan terkait makna Abtar memiliki banyak makna diantaranya terputus dari kebaikan, ada pula yang menyebut selalu dalam keburukan dan yang lain mengatakan itu merupakan gelar bagi orang yang tidak memiliki anak laki-laki dan saudara laki-laki.

3. Bahwa nilai edukatif pada ayat pertama adalah nilai syukur yakni mengakui dengan hati, lalu di ucapkan dengan lisan dan dilaksanakan/ di implementasikan dengan anggota badan. Sementara nilai edukatif pada ayat kedua ialah nilai spiritual yang mana termanifestasikan dalam ibadah sholat (Hablun minallah) dan nilai sosial yang mana termanifestasikan dalam ibadah qurban (Hablun minannas). Sedangkan nilai edukatif pada ayat ketiga adalah nilai semangat juang yang tergambar dalam amal ma'ruf nahi mungkar dan nilai ketegaran yang di iringi dengan nilai tanggung jawab, semua itu tergambarkan dengan bahwa tiap orang pasti akan mendapat balasan sesuai amalannya.

\section{Daftar Pustaka}

Adriantoni. (2019). Nilai-Nilai Pendidikan Yang Terdapat Dalam Surat Al-Insan Ayat 23-26. Murabby: Jurnal Pendidikan Islam. 2 (2). 113-121

Al-Qurthubi, Abu Abdillah. (2006). Al-Jami' Li Ahkam Al-Qur'an, cet. 1 Juz 22. 
Beirut, Libanon: Ar Risalah Publishers

Aufa, Ari Abi. (2019). Nilai-Nilai Pendidikan Dalam Surat Ad Dhuha. Al Aufa: Jurnal Pendidikan dan Kajian Keislaman. 1 (1). 10-20

Aulia, Firdaus. (2020). Keteladanan Akhlak Nabi Ibrahim AS: Kajian Terhadap Ayat-ayat Pesan Moral. Tadabbur: Jurnal Peradaban Islam. 2 (1). 170-189

Ar-rowi, Abdulloh Ahmad. (2019). Syarkhul Barsawi Ala Tafsir Surat Al Kautsar Lil Imam Badhowi. Majalah Ulum Islamiyah: Journal of Islamic Science. 1 (20). 122-164

Azwar, Saifuddin. (2009). Metode Penelitian. Yogyakarta: Pustaka Pelajar

Djunaid, Hamzah. (2014). Konsep Pendidikan Dalam Alquran (Sebuah Kajian Tematik. Lentera Pendidikan. 17 (1). 139-150

Fatmawati, Mila dkk. (2018). Analisis Semantik Kata Syukur Dalam Alquran. AlBayan: Jurnal Studi Al-Qur"an dan Tafsir. 3 (1). 90-100

Hamzah, Nur Alim dan Sulman. (2019). Ikhlas Dalam Beribadah Sesuai Tuntunan Al-Qur'an Dan Hadits. Jurnal Ushuluddin Adab dan Dakwah. 2 (1). 65-73

Hamid, Abdul. (2017). Globalisasi Dan Tantangan Dakwah. KORDINAT . 16 (1). 15-30

Hidayah, Inayatul. (2019). Nilai-Nilai Pendidikan Dalam Ayat-Ayat MuhkamMutasyabih Dan Implikasinya Di Dunia Pendidikan. Tasyri'. 26 (2). 129137

Islamiyah, Admin Maktabah. (2021). Asbabun Nuzul (Irdhu Taqlidiy), , diakses pada 07 Agustus 2021 pukul 10.29

Iyyas, Riham Abu. (2021). Ma Asbabu Nuzul Surat Al Kautsar, diakses pada 08 Agustus 2021 pukul 11.25

Kamaruddin, Kasimah dkk. (2021). Analisis Lafaz 'AmMenurut Imam al-Shafi'i dalam al-Risalah. BITARA International Journal of Civilizational Studies and Human Sciences. 4 (1). 53-61

Kholil, Adil Muhammad. (2017). Awwala Marrotin Atadabbarul Qur'an, Cet. 13. Kuwait: Asby Intregated Advertising Solution

Mahmud. (2011). Metode Penelitian Pendidikan. Bandung: Pustaka Setia

Nurasykim, M. Fathir Ma"eruf. (2019). Strategi Rasulullah Dalam Pengembangan Dakwah Pada Periode Mekkah. Jurnal At-Taujih Bimbingan Dan Konseling Islam. 2 (1). 108-125

Ridho, Miftahur. (2018). Ujaran Kebencian dalam Dakwah: Analisis tentang Pengejawantahan Ide Amar Ma'ruf Nahi Mungkar di Kalangan Para Da'i di Kalimantan Timur. Lentera. 2 (1). 27-48

Sari, Dewi Purnama. (2017). Pendidikan Karakter Berbasis Al-Quran. Islamic Counseling. 1 (1). 1-24

Sholeh, Moh. Jufriyadi. (2018). Tafsir Al-Qurtubi: Metodologi, Kelebihan Dan Kekurangannya. Jurnal Reflektika. 13 (1). 49-66

Simanjuntak, Dahliati. (2019). Faktor-Faktor Yang Mempengaruhi Kurangnya Kesadaran Masyarakat Dalam Berkurban. Jurnal Al-Maqasid Jurnal 
Kesyariahan dan Keperdataan. 5 (2). 258-270

Al-Fikri: Jurnal Studi dan Penelitian Pendidikan Islam Vol. 04 No. 01 (2021) : 68 - 81

Available online at http://jurnal.unissula.ac.id/index.php/fikri/issue/archive 